\title{
ENHANCING PROSPECTIVE TEACHERS' CREATIVE THINKING SKILLS: A STUDY OF THE TRANSITION FROM STRUCTURED TO OPEN INQUIRY CLASSES
}

\author{
Agus Ramdani *, I Putu Artayasa, Muhammad Yustiqvar, Nina Nisrina \\ Universitas Mataram, Mataram, Indonesia \\ *e-mail: aramdani07@unram.ac.id
}

\begin{abstract}
Creative thinking skills are considered to have a positive correlation with students' academic achievement. Thus, they need to be developed through the learning process. To successfully develop these skills, an appropriate learning model is needed. This research aims to determine the improvement of the creative thinking skills of prospective teachers who learned using structured, guided, and open inquiries. This quasi-experimental research used an untreated control group design with pretest and posttest. A total sample of 118 students was selected and distributed into structured, guided, and open inquiry classes. The research instrument consisted of 18 creative thinking skill items applied to the pretest and posttest. The data analysis was performed using ANCOVA and LSD tests. The results show that the mean score of the open inquiry class was higher and significantly different compared to those of the other two classes. However, the mean scores of the two classes were not significantly different. Therefore, it can be concluded that the implementation of the open inquiry model led to a higher increase in creative thinking skills compared to those of the structured and guided inquiry models.
\end{abstract}

Keywords: creative thinking skills, structured inquiry, guided inquiry, open inquiry

\section{PENINGKATAN KETERAMPILAN BERPIKIR KREATIF CALON GURU: TRANSISI DARI KELAS INKUIRI TERSTRUKTUR KE INKUIRI TERBUKA}

\begin{abstract}
Abstrak: Keterampilan berpikir kreatif berkorelasi positif dengan prestasi akademik mahasiswa sehingga pengembangan keterampilan tersebut perlu dilakukan dalam proses pembelajaran. Keberhasilan pengembangan keterampilan tersebut dapat dilakukan melalui implementasi model pembelajaran yang tepat. Tujuan penelitian ini adalah untuk menganalisis peningkatan keterampilan berpikir kreatif mahasiswa calon guru dari yang belajar menggunakan model inkuiri terstruktur ke inkuiri terbimbing dan terbuka. Penelitian ini merupakan quasy experiment dengan rancangan untreated control group design with pretest and posttest. Subjek penelitian berjumlah 118 mahasiswa yang terdistribusi ke dalam kelas inkuiri terstruktur, terbimbing dan terbuka. Instrumen penelitian berupa 18 item tes keterampilan berpikir kreatif yang diterapkan pada pretes dan postes. Analisis data dilakukan dengan AN-COVA yang dilanjutkan dengan uji LSD. Hasil penelitian menunjukkan rata-rata skor tes kelas inkuiri terbuka lebih tinggi dan berbeda signifikan dengan rata-rata skor dua kelas inkuiri lainnya, sementara rata-rata skor kedua kelas tersebut tidak berbeda signifikan. Kesimpulan dari penelitian adalah implementasi model inkuiri terbuka menyebabkan peningkatan keterampilan berpikir kreatif yang lebih tinggi dibandingkan dengan implementasi inkuiri terstruktur dan terbimbing.
\end{abstract}

Kata Kunci: keterampilan berpikir kreatif, inkuiri terstruktur, inkuiri terbimbing, inkuiri terbuka

\section{INTRODUCTION}

The enhancement of students' creative thinking skills is needed in the 21 st century in order to optimally compete in various work sectors (Anazifa \& Djukri, 2017; Kivunja, 2015; Nur et al., 2020). This development also helps students solve daily problems and provides them with an edge in the working sector, both in open new businesses and as employees of a company (Malik \& Setiawan, 2015). They also help the students generate creative ideas, which are needed to carry out their various activities. Also, students with creative thinking skills are observed to gain deeper understandings, therefore, increasing the effectiveness of their research results (Huang et al., 2020; Sumarni \& Kadarwati, 2020). Moreover, the creative thinking skills for prospective teacher students are needed in producing innovative learning strategies, which are found to contribute to the improvement of educational qualities (Beetlestone, 2010; Hudha, Hakim, et al., 2018; Ramdani \& Artayasa, 2020; Siburian et al., 2019). 
Currently, the learning process at many universities in Indonesia is still carried out based on the traditional method of providing lectures or conducting experiments (Hudha, Aji, et al., 2018; Ndiung, 2020; Ramadhani et al., 2019; Syuhendri, 2017). This learning model emphasizes the process of transferring knowledge from lecturers to students, or confirming theory or experimental results through traditional practicums (Chu et al., 2021). The results show that conventional learning did not lead to an increase in students' creative thinking skills (Ndiung, 2020; Rudibyani, 2019; Zubaidah et al., 2017) as they seem to need new strategies that enable them to be more active without being affected, in the educational sector (Hadisaputra et al., 2020; Yustiqvar et al., 2019).

A new strategy that requires the application of a learning model to facilitate students' creative thinking skills development is known to be indispensable. Also, the process of providing challenges to students is found to spur the development of their creative thinking skills, during learning (Duran \& Dökme, 2016; Trnova $\&$ Trna, 2014). The learning related to problems in daily activities is also believed to have the ability to encourage the enhancement of students' creative thinking skills (Chin \& Chia, 2010; Henriksen et al., 2017; Montag-Smit \& Maertz, 2017). The act of addressing topics of students' interests is also known to facilitate the development of their creative skills (Alencar et al., 2017; Yulianti et al., 2020). Therefore, creative thinking skills are very important in the educational sector, which are to be developed in prospective teacher students (Ramdani \& Artayasa, 2020).

In order to develop a very good creative thinking skills, learning process needs to be indispensable and challenging. A learning model is urgently needed to create a very good learning process to improve creative thinking skills. One of the best models for this process is inquiry. Garrison and Vaughan (2013) agree that inquiry has a very big impact in triggering students' ideas. Students are allowed to design everything they want, and inquiry supports them in identifying every factor related to a problem that they should solve. Akyol et al. (2009) also said that the inquiry framework comprises three overlapping elements: social presence, cognitive presence, and teaching presence. In a community of inquiry, deep learning occurs through the interaction of these three presences.

Furthermore, inquiry learning is a model that has the ability to equip students with the skills that are important to make discoveries through problem-solving activities. According to Gunawan et al. (2021), this learning model is very suitable for students in Indonesia. Lott (2011) also stated that inquiry is an activity to seek information, raise problems, and conduct investigations. However, Llewellyn (2013) stated that inquiry is an active exploration process, which involves using critical, creative, and logical thinking skills to solve interesting problems.

Moreover, Wahyudi et al. (2019) stated that inquiry learning provides an opportunity for students to investigate scientific problems of interest. In inquiry learning, students obtain the opportunity to construct new knowledge, through the exploration of various phenomena in their environment (Andrini, 2016; Spires et al., 2016). Chin and Chia (2010) stated that inquiry learning facilitates students to solve problems, which are related to daily activities in their environment.

Based on the characteristics of inquiry learning, implementation is observed to provide a positive indication for the development of students' creative thinking skills. The effect of this learning model on the development of students' creative thinking skills has been reported in several previous studies. Duran and Dökme (2016) and Anjarwani et al. (2020) stated that the implementation of inquiry learning increases self-confidence, scientific curiosity, and students' creative thinking skills. Also, Trnova and Trna (2014) stated that the implementation of inquiry learning promotes students' abilities to have open-ended questions and think creatively.

Llewellyn (2013) stated that the learning model is divided into four parts: demonstrated, structured, guided, and open (self-directed) inquiries. The characteristics of these four models, according to (Llewellyn, 2011) are: (1) Demonstrated inquiry, a process whereby a teacher conducts an experiment and presents the results to the students; (2) Structured inquiry, a process whereby students conduct experiments based on the problems and work procedures provided by the teacher but data processing and presentation are carried out in their own way; (3) Guided inquiry, a process whereby students conduct experiments based on problems provided by the teacher but the procedures are compiled by the students; and (4) Open inquiry, a process whereby students conduct experiments based on problems and experimental procedure, which are compiled by them. 
Generally, teachers are known to apply one inquiry learning model (Fuad et al., 2017) even though each model has different effects on developing students' skills during implementation. For example, the implementation of open inquiry cause students to be more involved in research projects, intense interactions, and deeper scientific understanding. However, the opportunity to document their results is less than that of students with guided inquiry (Sadeh \& Zion, 2012). Meanwhile, Zion and Mendelovici (2012) stated that the implementation of open inquiry is more effective in developing cognitive and procedural skills and higher critical and scientific thinking than structured and guided models.

Bunterm et al. (2014) stated that some weaknesses of implementing a higher level of inquiry (open and guided inquiry) are teachers' concerns about students' activities, which are out of control, as many are found to be frustrated in learning. Due to these weaknesses, many teachers eventually opted to implement structured inquiry. Also, Spires et al. (2016) stated that teachers' assistance, which is very high in learning, causes the students' thought and problem-solving processes to be disturbed. However, when the teachers' assistance is very low, such as in an open inquiry class, many students do not show expected progress, which in turn causes frustration in learning.

Based on the results of observations, the lower model of inquiry, namely structured inquiry, causes class activities to be more orderly because the lecturer provides adequate assistance to the implementation of student experiments. However, the weakness is that students do not think about the meaning of learning because they only follow existing work procedures. Furthermore, the lecturer has a more dominant role in learning, which causes students to be less creative in problem-solving.

Meanwhile, the guided and open inquiry models have advantages in terms of providing more opportunities for students to think about the meaning of learning and develop higher-order thinking skills, while the disadvantage is that the lecturer has less control over the class. This is in line with Zion and Mendelovici (2012) statement that open and guided inquiry need high-order thinking skills to explore more ideas to solve problems, design experiments collaboratively, and bring a lot of creative ideas. Therefore, Zion and Mendelovici (2012) also stated that there is still controversy among educators to determine the most effective inquiry learning models (structured, guided, or open) to be applied in schools.

Moreover, one of the skills that need to be developed by students in the 21st century is creative thinking due to its significant positive relationship with academic achievements (Beetlestone, 2010; Palaniappan, 2007). Therefore, it is necessary to conduct research on enhancing students' creative thinking skills by implementing three levels of inquiry models; from lower (structured) to higher (guided and open) levels of learning.

\section{METHODS}

This research employed a quasi-experimental design. It used a pretest and posttest model with a non-randomized control group (Ary et al., 2011) as shown in Table 1. Based on this design, each class was provided with the same pretest and posttest procedures and the application of different inquiry models (structured, guided, and open) during learning.

Table 1. Research Design

\begin{tabular}{cccc}
\hline Group & Pretest & Treatment & Posttest \\
\hline $\mathrm{E}_{1}$ & $\mathrm{O}_{1}$ & $\mathrm{X}_{1}$ & $\mathrm{O}_{2}$ \\
$\mathrm{E}_{2}$ & $\mathrm{O}_{3}$ & $\mathrm{X}_{2}$ & $\mathrm{O}_{4}$ \\
$\mathrm{E}_{3}$ & $\mathrm{O}_{5}$ & $\mathrm{X}_{3}$ & $\mathrm{O}_{6}$ \\
\hline
\end{tabular}

$\mathrm{X}_{1}$ : Structured inquiry

$\mathrm{X}_{2}$ : Guided inquiry

$\mathrm{X}_{3}$ : Open inquiry

E: Experiment

The research was conducted for eight weeks, with meetings that were held once every week in each class. The meeting length per session was 150 minutes, as the topics studied were measurement, substances and their changes, plants, animals, environmental pollution, and simple machines. A model lecturer that had previously been trained to apply structured, guided, and open inquiry learning was selected to teach the three classes.

Llewellyn (2013) stated that the syntax of the three models referred to six phases of activity in one inquiry cycle: (1) Inquisition, which involves starting with a question to be investigated; in structured and guided inquiry classes, questions we're often asked by the lecturer, compared to the open group, where students pose their own problems; (2) Acquisition, which involves brainstorming possible answers and problems; (3) Supposition, which involves the selection of an answer to be tested through experimental activities; (4) Implementation, which involves the compilation of a plan for experimental activities; in a structured inquiry class, the 
experimental design was provided by the lecturer, compared to the guided and open groups, where students compile their own model; (5) Summation involves students collecting evidence and drawing conclusions; and (6) Exhibition, which involves students sharing and communicating their results. Moreover, the activities of students in the three classes are described in Table 2.

The research subjects were students enrolled in the elementary school teacher education study program at a university in Mataram, studying science education courses with 278 students. There were a total of 118 students chosen as the sample, which were divided into three classes, namely structured, guided, and open inquiry models. They were selected using a purposive sampling technique in order to obtain a class with equal prior knowledge. Based on the faculty academic data from the previous semester, the average student achievement index in structured, guided, and open inquiry classes were $3.25,3.37$, and 3.37 , respectively. These results were also found to be insignificantly different $(\mathrm{F}(2.117)=2.813, \mathrm{p}=$ 0.064).

Table 2. Lecturer and Student Activities in Three Inquiry Models

\begin{tabular}{|c|c|c|c|c|c|}
\hline No. & Activity & Inquiry phase & $\begin{array}{l}\text { Structured } \\
\text { Inquiry }\end{array}$ & Guided Inquiry & Open Inquiry \\
\hline 1. & Submission of Problems & Inquisition & $\begin{array}{l}\text { Performed by } \\
\text { lecturers }\end{array}$ & $\begin{array}{l}\text { Performed by } \\
\text { lecturers }\end{array}$ & $\begin{array}{l}\text { Compiled by } \\
\text { students }\end{array}$ \\
\hline 2. & Submission of Hypotheses & Acquisition & $\begin{array}{l}\text { Performed by } \\
\text { students }\end{array}$ & $\begin{array}{l}\text { Performed by } \\
\text { students }\end{array}$ & $\begin{array}{l}\text { Performed by } \\
\text { students }\end{array}$ \\
\hline 3. & Selection of Hypotheses & Supposition & $\begin{array}{l}\text { Performed by } \\
\text { students }\end{array}$ & $\begin{array}{l}\text { Performed by } \\
\text { students }\end{array}$ & $\begin{array}{l}\text { Performed by } \\
\text { students }\end{array}$ \\
\hline 4. & $\begin{array}{l}\text { Preparation of Work } \\
\text { Procedures }\end{array}$ & Implementation & $\begin{array}{l}\text { Performed by } \\
\text { lecturers }\end{array}$ & $\begin{array}{l}\text { Compiled by } \\
\text { students }\end{array}$ & $\begin{array}{l}\text { Compiled by } \\
\text { students }\end{array}$ \\
\hline 5. & $\begin{array}{l}\text { Presentation of Data and } \\
\text { Drawing Conclusions }\end{array}$ & Summation & $\begin{array}{l}\text { Compiled by } \\
\text { students }\end{array}$ & $\begin{array}{l}\text { Compiled by } \\
\text { students }\end{array}$ & $\begin{array}{l}\text { Compiled by } \\
\text { students }\end{array}$ \\
\hline 6. & $\begin{array}{l}\text { Presentation of Investigation } \\
\text { Results }\end{array}$ & Exhibition & $\begin{array}{l}\text { Performed by } \\
\text { students }\end{array}$ & $\begin{array}{l}\text { Performed by } \\
\text { students }\end{array}$ & $\begin{array}{l}\text { Performed by } \\
\text { students }\end{array}$ \\
\hline
\end{tabular}

Table 3. Indicator Description for Each Question Number

\begin{tabular}{|c|c|c|c|c|}
\hline No. & Creativity Indicator & Descriptor & $\begin{array}{l}\text { Test } \\
\text { Form }\end{array}$ & $\begin{array}{c}\text { Test } \\
\text { Number }\end{array}$ \\
\hline \multirow[t]{4}{*}{1.} & \multirow[t]{4}{*}{ Curiosity (show curiosity) } & a. Having a desire to know something & \multirow[t]{4}{*}{ Essay } & 1 \\
\hline & & b. Interested in creative activities & & 2 \\
\hline & & c. Having a desire to do research & & 3 \\
\hline & & d. Interested in problems in their surroundings & & 4 \\
\hline \multirow[t]{2}{*}{2.} & \multirow{2}{*}{$\begin{array}{l}\text { Fluency (generate a number of } \\
\text { ideas) }\end{array}$} & a. Finding more answers & \multirow[t]{2}{*}{ Essay } & 5 \\
\hline & & $\begin{array}{l}\text { b. Not being resourceful in solving problems } \\
\text { nor having a good initiative }\end{array}$ & & 6 \\
\hline \multirow[t]{3}{*}{3.} & \multirow{3}{*}{$\begin{array}{l}\text { Originality (show new ideas } \\
\text { that are unique or unusual) }\end{array}$} & a. Generating different and unique ideas & \multirow[t]{3}{*}{ Essay } & 7 \\
\hline & & $\begin{array}{l}\text { b. Choosing appropriate technique or method } \\
\text { of work }\end{array}$ & & 8 \\
\hline & & c. Arranging new combinations & & 9 \\
\hline \multirow[t]{4}{*}{4.} & \multirow[t]{4}{*}{$\begin{array}{l}\text { Elaboration (present ideas in } \\
\text { detail) }\end{array}$} & $\begin{array}{l}\text { a. A systematic presentation throughout the } \\
\text { work, from beginning to end/closing }\end{array}$ & \multirow[t]{4}{*}{ Essay } & 10 \\
\hline & & b. Giving examples for each section & & 11 \\
\hline & & c. Giving examples from simple to complex & & 12 \\
\hline & & d. Breaking down the details of an object & & 13 \\
\hline \multirow[t]{3}{*}{5.} & \multirow{3}{*}{$\begin{array}{l}\text { Imagination (generate new } \\
\text { ideas or products) }\end{array}$} & a. Generating problem solving ideas & \multirow[t]{3}{*}{ Essay } & 14 \\
\hline & & $\begin{array}{l}\text { b. Providing recommendations to solve the } \\
\text { problems }\end{array}$ & & 15 \\
\hline & & $\begin{array}{l}\text { c. Making accurate predictions from limited } \\
\text { information }\end{array}$ & & 16 \\
\hline \multirow[t]{2}{*}{6.} & \multirow[t]{2}{*}{$\begin{array}{l}\text { Flexibility (show ideas with } \\
\text { many possibilities) }\end{array}$} & $\begin{array}{l}\text { a. Providing many alternatives to solve the } \\
\text { problems }\end{array}$ & \multirow[t]{2}{*}{ Essay } & 17 \\
\hline & & b. Openness to new experiences & & 18 \\
\hline
\end{tabular}


The instrument of this research was in the form of descriptive questions (essay), consisting of 18 items. The research data were in the form of pre and posttest scores assessing creative thinking skills. Based on the indicators of creative thinking skills from Greenstein (2012), the tests consisted of six factors, namely curiosity, fluency, originality, elaboration, imagination, and flexibility. Based on the results of the product-moment correlation test, all items were found to be valid ( $p$ $<0.05$ ) and reliable, with a Cronbach Alpha coefficient of 0.84 (Sarwono, 2015). Indicator descriptions for each question item are presented in Table 3.

The data for the three classes of inquiry were obtained using the pretest and posttest methods. The data from the pretest and posttest from the three inquiry classes were further examined using ANCOVA (Analysis of Covariance) with an alpha of 0.05. The Analysis was also complemented by the Post-Hoc LSD (Least Significance Difference) test at an alpha of 0.05 to determine the significance of differences between the mean values being compared. Also, data analysis was performed with the Statistical Package for the Social Sciences (SPSS) Version 22 for Windows.

\section{FINDINGS AND DISCUSSION \\ Findings}

The results of observations on the lecturer's and students' activities in each phase of the three Inquiry Models are presented in Table 4. It describes the activities of lecturers and students for each phase of three inquiry models. Each activity is different in accordance with the type of the three models. From Table 4, it can be seen that each phase has a specific characteristic on how the lecturer teaches students to learn about science. The biggest difference is shown in the implementation phase, where the structured type needs assistance from the lecturer, while guided and open types give a chance to design by themselves.

The results show that students that applied the structured inquiry model had the lowest mean pretest score at 36.68 , which was observed not to be very different from the outcome of those in guided and open classes. However, the results of the posttest show that the open inquiry class students had the highest score (62.75), which was quite different from the outcome of those in the structured and guided groups, as indicated in Table 5. These results show that the prior knowledge of students for each class is almost the same. The number of students for each class was almost equal and purposely chosen according to the purpose of the research: to differentiate the type of inquiry. The results of posttest show that the open inquiry class obtained the highest score while the other two obtained a nearly equal score after learning with structured and guided inquiries.

Based on the Kolmogorov-Smirnov normality test, the pre and post test data show a normal distribution ( $\mathrm{p}$ pretest $=0.983>0.05, \mathrm{p}$ posttest $=0.984>0.05)$. Both data also had homogeneous variances, with Levene's test results showing the p-pretest and p-posttest to be $0.596>0.05 \& 0.300>0.05$, respectively.

The results of observations show that the open inquiry class had the highest value on all six indicators of the students' creative skills. Also, the guided inquiry class had a higher score than the structured group on indicators of curiosity, elaboration, imagination, and flexibility. However, it possessed a lower score on the originality indicator (Figure 1).

The ANCOVA results also show that there was a significant difference in the mean scores of the three inquiry classes, as indicated from the value of $F(2.114)=24.439, p<0.001$ in Table 6 . Based on the results, the open inquiry class had an estimated marginal mean score of 62,376, which was found to be higher than those obtained by the guided and structured groups, as shown in Table 7. The Post Hoc test using the LSD analysis at an alpha of 0.05 also shows that the students' mean scores in the open inquiry class were significantly higher than those in the other two groups $(\mathrm{p}<$ 0.001 ). However, the mean score of the guided and structured inquiry classes did not show a significant difference with $\mathrm{p}=0.121$ or $\mathrm{p}>0.05$.

\section{Discussion}

This research focused on creative thinking skills as reflected in the ideas, curiosity, detailed answers, and flexible problem-solving in students' daily lives. The results show that there was a difference in the mean score between the three inquiry models, as the LSD test further shows that the value of the open inquiry class was significantly different from the other groups. However, the structured and guided inquiries were not significantly different.

The observation results on the posttest score also show that the open inquiry class had the highest score on all indicators, i.e., curiosity, fluency (a large variety of presented ideas), originality (the uniqueness of the presented ideas), elaboration (the delivery of detailed ideas), 
imagination (the ability to convey new ideas), and flexibility (a tolerant attitude towards new ideas or experiences). Meanwhile, the structured and guided inquiry classes had almost the same score on the six indicators of creative thinking skills. This results were in line with those of Zion and Mendelovici (2012) study, which stated that implementing an open inquiry approach has led to a higher enhancement in students' creativity than other models.

Also, the open inquiry class students had higher creative thinking skills than other model groups due to their high responsibility in learning. Based on the syntax of each model, the open inquiry students had full responsibility, which was found to have started from the first phase of the syntax (inquisition phase), where they were told to compile experimental problems. After-ward, students were also told to compile an experimental design in the implementation phase, obtain and process the data in the summation phase, and draft out conclusions (Llewellyn, 2011).

The provision of this big responsibility was found to have encouraged open inquiry class students to think more creatively to create learning efforts. Therefore, the assigned tasks were completed according to the time agreed with the lecturer. This was in accordance with Munro (2015) and Antwi et al. (2019), which stated that creativity tends to occur when an individual has been provided with the responsibility of a task, as well as the permission to take risks for their work. According to Yusnaeni et al. (2017) and Romli et al. (2018), providing responsibility to students for independent learning was observed to enhance their creative thinking skills.

Table 4. Activities of the Lecturer and Students in Each Phase of the Three Inquiry Models

\begin{tabular}{|c|c|c|c|c|c|c|}
\hline \multirow{3}{*}{ Phases } & \multicolumn{6}{|c|}{ Inquiry Models } \\
\hline & \multicolumn{2}{|c|}{ Structured Inquiry } & \multicolumn{2}{|c|}{ Guided Inquiry } & \multicolumn{2}{|c|}{ Open Inquiry } \\
\hline & Lecturer & Students & Lecturer & Students & Lecturer & Students \\
\hline Inquisition & $\begin{array}{l}\text { Present a } \\
\text { phenomena } \\
\text { and provide a } \\
\text { research } \\
\text { problem }\end{array}$ & $\begin{array}{l}\text { Give some } \\
\text { questions } \\
\text { related to the } \\
\text { phenomena }\end{array}$ & $\begin{array}{l}\text { Present a } \\
\text { phenomenon } \\
\text { and identify a } \\
\text { research } \\
\text { problem }\end{array}$ & $\begin{array}{l}\text { Give some } \\
\text { questions } \\
\text { related to the } \\
\text { phenomena }\end{array}$ & $\begin{array}{l}\text { Present a } \\
\text { phenomenon } \\
\text { related to the } \\
\text { topic }\end{array}$ & $\begin{array}{l}\text { Give some } \\
\text { questions } \\
\text { related to the } \\
\text { phenomena }\end{array}$ \\
\hline Acquisition & $\begin{array}{l}\text { Guide the } \\
\text { students in } \\
\text { formulating } \\
\text { hypotheses }\end{array}$ & $\begin{array}{l}\text { Brainstorm } \\
\text { and } \\
\text { formulate } \\
\text { hypotheses }\end{array}$ & $\begin{array}{l}\text { Guide the } \\
\text { students in } \\
\text { formulating } \\
\text { hypotheses }\end{array}$ & $\begin{array}{l}\text { Brainstorm } \\
\text { and } \\
\text { formulate } \\
\text { hypotheses }\end{array}$ & $\begin{array}{l}\text { Guide the } \\
\text { students in } \\
\text { formulating } \\
\text { hypotheses }\end{array}$ & $\begin{array}{l}\text { Brainstorm } \\
\text { to and } \\
\text { formulate } \\
\text { hypotheses }\end{array}$ \\
\hline Supposition & $\begin{array}{l}\text { Assist the } \\
\text { students in } \\
\text { formulating } \\
\text { hypotheses }\end{array}$ & $\begin{array}{l}\text { Formulate } \\
\text { the } \\
\text { hypotheses } \\
\text { that will be } \\
\text { tested in the } \\
\text { experiment }\end{array}$ & $\begin{array}{l}\text { Assist the } \\
\text { students in } \\
\text { formulating } \\
\text { hypotheses }\end{array}$ & $\begin{array}{l}\text { Formulate } \\
\text { the } \\
\text { hypotheses } \\
\text { that will be } \\
\text { tested in the } \\
\text { experiment }\end{array}$ & $\begin{array}{l}\text { Assist the } \\
\text { students in } \\
\text { formulating } \\
\text { hypotheses }\end{array}$ & $\begin{array}{l}\text { Formulate } \\
\text { the } \\
\text { hypotheses } \\
\text { that will be } \\
\text { tested in the } \\
\text { experiment }\end{array}$ \\
\hline $\begin{array}{l}\text { Implemen- } \\
\text { tation }\end{array}$ & $\begin{array}{l}\text { Give experi- } \\
\text { mental } \\
\text { procedure to } \\
\text { students }\end{array}$ & $\begin{array}{l}\text { Perform the } \\
\text { experiment } \\
\text { based on the } \\
\text { procedure }\end{array}$ & $\begin{array}{l}\text { Assist the } \\
\text { students in } \\
\text { designing the } \\
\text { experimental } \\
\text { procedure }\end{array}$ & $\begin{array}{l}\text { Design the } \\
\text { experimental } \\
\text { procedure } \\
\text { and perform } \\
\text { the experi- } \\
\text { ment }\end{array}$ & $\begin{array}{l}\text { Assist the } \\
\text { students in } \\
\text { designing the } \\
\text { experimental } \\
\text { procedure }\end{array}$ & $\begin{array}{l}\text { Design the } \\
\text { experimental } \\
\text { procedure } \\
\text { and perform } \\
\text { the } \\
\text { experiment }\end{array}$ \\
\hline Summation & $\begin{array}{l}\text { Assist } \\
\text { students in } \\
\text { collecting } \\
\text { and } \\
\text { analysing the } \\
\text { experimental } \\
\text { data }\end{array}$ & $\begin{array}{l}\text { Collect and } \\
\text { analyse the } \\
\text { experimental } \\
\text { data }\end{array}$ & $\begin{array}{l}\text { Assist } \\
\text { students in } \\
\text { collecting } \\
\text { and } \\
\text { analysing the } \\
\text { experimen- } \\
\text { tal data }\end{array}$ & $\begin{array}{l}\text { Collect and } \\
\text { analyse the } \\
\text { experimental } \\
\text { data }\end{array}$ & $\begin{array}{l}\text { Assist the } \\
\text { students in } \\
\text { collecting } \\
\text { and analy- } \\
\text { sing the } \\
\text { experimental } \\
\text { data }\end{array}$ & $\begin{array}{l}\text { Collect and } \\
\text { analyse the } \\
\text { experimental } \\
\text { data }\end{array}$ \\
\hline Exhibition & $\begin{array}{l}\text { Facilitate } \\
\text { student to } \\
\text { present the } \\
\text { experiment } \\
\text { results }\end{array}$ & $\begin{array}{l}\text { Present the } \\
\text { experiment } \\
\text { results }\end{array}$ & $\begin{array}{l}\text { Facilitate } \\
\text { student to } \\
\text { present the } \\
\text { experiment } \\
\text { results }\end{array}$ & $\begin{array}{l}\text { Present the } \\
\text { experiment } \\
\text { results }\end{array}$ & $\begin{array}{l}\text { Facilitate } \\
\text { student to } \\
\text { present the } \\
\text { experiment } \\
\text { results }\end{array}$ & $\begin{array}{l}\text { Present the } \\
\text { experiment } \\
\text { results }\end{array}$ \\
\hline
\end{tabular}


Table 5. The Mean of Pretest and Posttest Scores for Students' Creative Thinking Skills from Three Inquiry Models

\begin{tabular}{lccc}
\hline Learning model & N & Pretest & Posttest \\
\hline Structured Inquiry & 41 & 36.68 & 52,00 \\
Guided Inquiry & 39 & 40.24 & 53,42 \\
Open Inquiry & 38 & 38.92 & 62,75 \\
Total & 118 & & \\
\hline
\end{tabular}

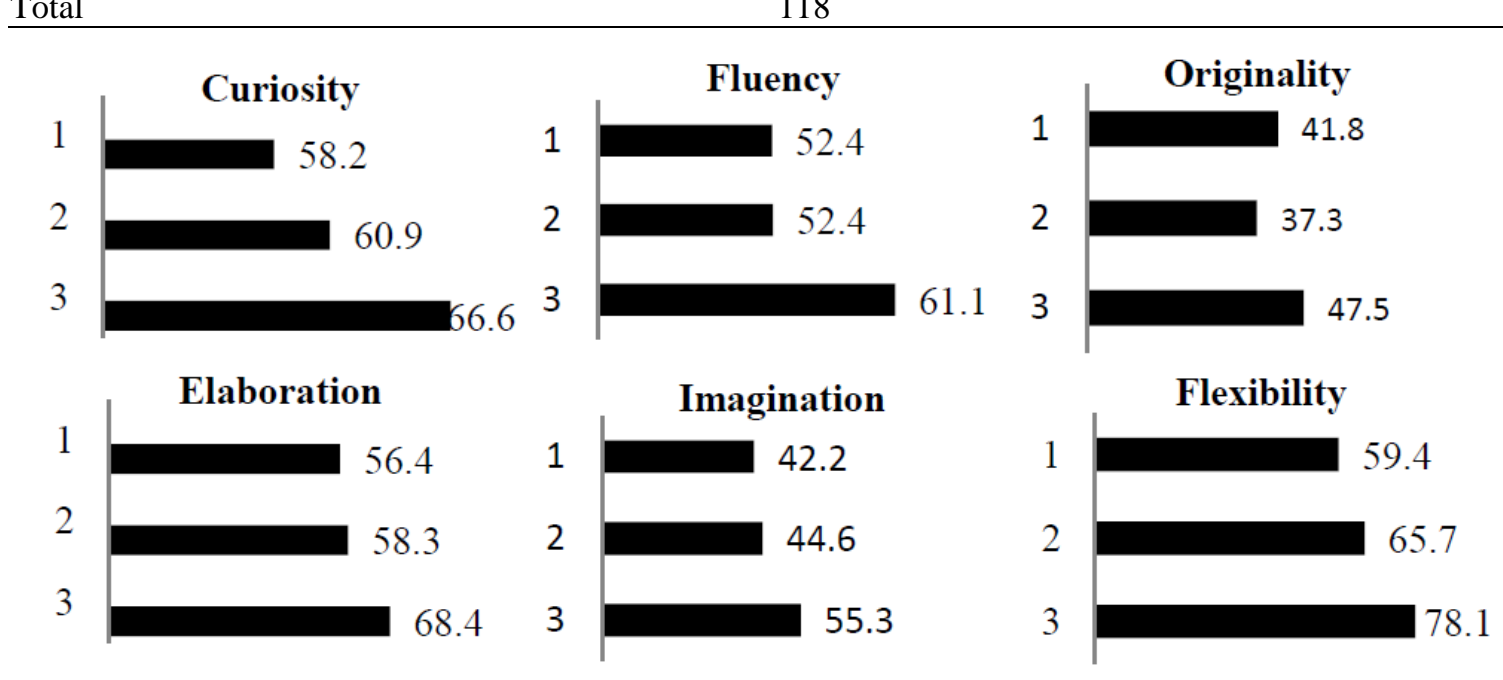

Scores for Each Indicator of Creative Thinking Skills

1. Structured Inquiry 2. Guided Inquiry 3. Open Inquiry

Figure 1. Posttest Scores of Six Indicators on Student Creative Thinking Skills

Table 6. ANCOVA Results

\begin{tabular}{lcccc}
\hline Source & $\boldsymbol{d} \boldsymbol{f}$ & Mean Square & $\boldsymbol{F}$ & Sig. $(\boldsymbol{p})$ \\
\hline Corrected Model & 3 & 3527.742 & 70.278 & $<.001$ \\
Intercept & 1 & 740.069 & 14.743 & $<.001$ \\
Pretest & 1 & 7938.199 & 158.142 & $<.001$ \\
Inquiry Model & 2 & 1226.738 & 24.439 & $<.001$ \\
Error & 114 & 50.197 & & \\
Total & 118 & & & \\
Corrected Total & 117 & & & \\
\hline
\end{tabular}

Table 7. Estimated Marginal Mean and LSD Test Results from Three Inquiry Models

\begin{tabular}{lccc}
\hline Learning Model & Estimated Marginal Mean & Std. Error & LSD notation on $\boldsymbol{\alpha}=\mathbf{0 . 0 5}$ \\
\hline Open Inquiry & 62.376 & 1.150 & $\mathrm{a}$ \\
Guided Inquiry & 51.579 & 1.144 & $\mathrm{~b}$ \\
Structured Inquiry & 54.104 & 1.119 & $\mathrm{~b}$ \\
\hline
\end{tabular}

Furthermore, to provide open inquiry responsibilities, students were observed to have implications for their freedom to choose their own experimental problems, which were not carried out by other model classes (Llewellyn, 2011). The activities show this for each phase in open inquiry, which allows students to choose the problem, design the procedure, collect data, and reach a conclusion.

In order to pose problems and devise solutions, it was found that providing flexibility to students would encourage them to come up with new ideas during learning (Kivunja, 2015; Pretorius et al., 2017). This was in line with
Trnova and Trna (2014), which also stated that the provision of opportunities, flexibility, and comfortability in problem-solving processes was a strategy that enhanced students' creative thinking skills during learning.

Most opportunities to observe phenomena that existed in the environment also occurred in the implementation of open inquiry. This was the opportunity that impacted open inquiry students in order to select experimental problems that matched their interests. This research also showed that many experimental problems experienced by open inquiry class students were issues within their environments, such as, "What 
types of simple aircraft are there in the household environment?" and "Does staple food contain starch, protein, and glucose?". Also, providing students with the opportunity to explore and select experimental problems in their environment helped them develop learning according to their interests and enhance higherorder creative thinking skills (Hugerat \& Kortam, 2014; Hwang et al., 2018). Suryawati and Osman (2018) and Ratnasari et al. (2019) also stated that observing the phenomena in their environment stimulated students' creativity in order for them to think more scientifically in learning.

Meanwhile, students in structured and guided inquiry classes did not significantly differ in creative thinking skills. The similarity factor in the experimental problems studied by the students of these two classes was possibly the cause of the insignificant difference in their creative thinking skills. Due to the fact that the two inquiry classes conducted an experiment based on the problem formulation compiled by the lecturer, the students were not provided with the opportunities to develop creative thinking skills towards discovering interesting problems. Moreover, this impact was less stimulating for the students' curiosity levels. According to Bennett (2016), providing students with the opportunity to discover problems and encouraging their curiosities and ambitions freely were factors that supported the development of creative thinking skills.

Based on the result, the indicator of creative thinking skills increased mostly in flexibility and elaboration. These results show that the inquiry model has a very big impact in triggering students to give many different ideas. Students are flexible in describing many solutions to one problem. By having many ideas, students are also very good at elaborating those to create a wide and clear solution. The score of flexibility and elaboration support this argumentation.

Gunawan et al., (2018) agreed with this as their research showed a significant result in increasing students' creativity with the 21 stcentury learning model that supports students' flexibility and elaboration. Gunawan et al. (2020) stated that the inquiry learning model gives students the opportunity to describe phenomena scientifically and create a great inquiry procedure to describe a good solution.

Inquiry learning provides students to learn about their surroundings and get them more curious about them. Despite the general model form, all of the types of inquiry models give an impact on students' creative thinking skills. Each type of the model gives different vibes in increasing the skills. Based on the result, the structured inquiry has the highest score in N-gain than the other types of inquiry, even though they have a small score difference.

Hensley (2020) explained that all types of inquiry could cultivate creativity through mindfulness. Especially for structured, lecturer can give full attention and guidance toward students. For guided inquiry, the conditions depend of lecturer and students interaction whether they can get a proper guide in exclaiming the solution. Hensley (2020) also stated that inquiry with open type gives a different vibe for each student to set their mind to be independent.

Based on each indicator of creativity that the inquiry model influenced, flexibility shows a higher score than the other. Inquiry gives a positive effect in stimulating students' mindset. The high score in flexibility shows that students can give a lot of ideas in solving a problem. Gunawan et al. (2021) stated that inquiry brings a big opportunity for students to describe the phenomena and make sure they can have a wide space in combining their ideas. Nisrina et al. (2017) also support this argumentation based on their experiment in creativity. Collaboration and independence give students a wide range of ideas to solve a problem effectively.

Creative thinking skills were also needed to support student success in learning, such as increasing their effectiveness in laboratory activities (Hernawati et al., 2018; Ramdani \& Artayasa, 2020). These skills also had a significant positive relationship with students' academic achievements (Beetlestone, 2010; Palaniappan, 2007). Moreover, creative thinking skills can also be developed through practices (Gube \& Lajoie, 2020). Therefore, among the three models tested in this research, the open inquiry implementation was concluded to be the most effective learning design used to train and enhance students' creative thinking skills.

\section{CONCLUSION}

The implementation of the inquiry model was carried out in five phases, namely inquisition, acquisition, supposition, implementation, summation, and exhibition. Most lecturer's assistance was given using a structured inquiry model, starting from the inquisition phase to provide work procedures in the implementation phase. Then the assistance was reduced in the 
guided inquiry model, which only provided experimental problems in the inquisition phase, while in the open inquiry model, the lecturer fully provided opportunities for students from determining experimental problems to present experimental results in the exhibition phase.

The open inquiry model led to the highest enhancement in creative thinking skills compared to other inquiry designs. However, the structured and guided inquiry models did not cause a significant difference in improving students' creative thinking skills. The impact for each inquiry learning model obtained a very good score for each indicator of creative thinking skills. Based on the results, students' elaboration and flexibility indicators are higher than other indicators after learning with an inquiry model. The open inquiry model provided a very good trigger and motivation based on the results of flexibility and elaboration scores.

We can also conclude that the open inquiry model can enhance prospective teachers' creative thinking skills, especially in describing many different ideas used to solve problems. The results of this study suggest that open inquiry is the most suitable model for enhancing prospective teachers' creative thinking skills.

\section{ACKNOWLEDGMENTS}

The author would like to thank the University of Mataram, especially the Faculty of Teacher Training and Education (FKIP), which has facilitated this research activity to run smoothly.

\section{REFERENCES}

Akyol, Z., Garrison, D. R., \& Ozden, M. Y. (2009). Development of a community of inquiry in online and blended learning contexts. Procedia - Social and Behavioral Sciences, 1(1), 1834-1838. https://doi.org/10.1016/j.sbspro.2009.01.3 24

Alencar, E. M. L. S. de, Fleith, D. de S., \& Pereira, N. (2017). Creativity in higher education: Challenges and facilitating factors. Temas Em Psicologia, 25(2), 553-561. https://doi.org/10.9788/TP2017.2-09

Anazifa, R. D., \& Djukri, D. (2017). Projectbased learning and problem-based learning: Are they effective to improve student's thinking skills? Jurnal Pendidikan IPA Indonesia, 6(2), 346. https://doi.org/10.15294/jpii.v6i2.11100

Andrini, V. S. (2016). The effectiveness of inquiry learning method to enhance students' learning outcome: A theoritical and empirical review. Journal of Education and Practice, 7(3), 38-42.

Anjarwani, R., Doyin, M., \& Indiatmoko, B. (2020). Guided inquiry learning with outdoor activities setting to improve critical thinking ability and science process skills of elementary school students. Journal of Primary Education, 9(2), 129-135. https://doi.org/10.15294/jpe.v9i2.36178

Antwi, C. O., Fan, C., Aboagye, M. O., Brobbey, P., Jababu, Y., Affum-Osei, E., \& Avornyo, P. (2019). Job demand stressors and employees' creativity: A within-person approach to dealing with hindrance and challenge stressors at the airport environment. The Service Industries Journal, 39(3-4), 250-278. https://doi.org/10.1080/02642069.2018.15 20220

Ary, D., Jacobs, L. C., \& Razavieh, A. (2011). Pengantar penelitian dalam pendidikan (A. Furchan (trans.); 4th ed.). Pustaka Pelajar.

Beetlestone, F. (2010). Creative learning: Strategi pembelajaran untuk melesatkan kreatifitas siswa (N. Yusron (trans.); 5th ed.). Nusa Media.

Bennett, D. (2016). Enacting strategies for graduate employability: How universities can best support students to develop generic skills.

Bunterm, T., Lee, K., Ng Lan Kong, J., Srikoon, S., Vangpoomyai, P., Rattanavongsa, J., \& Rachahoon, G. (2014). Do different levels of inquiry lead to different learning outcomes? A comparison between guided and structured inquiry. International Journal of Science Education, 36(12), 1937-1959.

https://doi.org/10.1080/09500693.2014.88 6347

Chin, C., \& Chia, L.-G. (2010). Implementing problem-based learning in biology. Journal of Biological Education, 1, 6975.

https://doi.org/10.1080/00219266.2004.96 
55904

Chu, S. K. W., Reynolds, R. B., Tavares, N. J., Notari, M., \& Lee, C. W. Y. (2021). $21 s t$ century skills development through inquiry-based learning from theory to practice. Springer. https://doi.org/10.1007/978-981-10-24818

Duran, M., \& Dökme, İ. (2016). The effect of the inquiry-based learning approach on student's critical thinking skills. Eurasia Journal of Mathematics, Science \& Technology Education, 12(12), 28872908.

https://doi.org/10.12973/eurasia.2016.023 $11 \mathrm{a}$

Fuad, N. M., Zubaidah, S., Mahanal, S., \& Suarsini, E. (2017). Improving junior high schools' critical thinking skills based on test three different models of learning. International Journal of Instruction, 10(01), 101-116. https://doi.org/10.12973/iji.2017.1017a

Garrison, D. R., \& Vaughan, N. D. (2013). Institutional change and leadership associated with blended learning innovation: Two case studies. The Internet and Higher Education, 18, 2428.

https://doi.org/10.1016/j.iheduc.2012.09.0 01

Greenstein, L. (2012). Assessing 21st century skills: A guide to evaluating mastery and authentic learning. Corwin Press.

Gube, M., \& Lajoie, S. (2020). Adaptive expertise and creative thinking: A synthetic review and implications for practice. Thinking Skills and Creativity, 35,100630 .

https://doi.org/10.1016/j.tsc.2020.100630

Gunawan, G., Harjono, A., Sahidu, H., \& Nisrina, N. (2018). Improving students' creativity using cooperative learning with virtual media on static fluida concept. Journal of Physics: Conference Series, 1006, 012016. https://doi.org/10.1088/17426596/1006/1/012016

Gunawan, G., Jufri, A. W., Nisrina, N., AlIdrus, A., Ramdani, A., \& Harjono, A. (2021). Guided inquiry blended learning tools (GI-BL) for school magnetic matter in junior high school to improve students' scientific literacy. Journal of Physics: Conference Series, 1747(1), 012034. https://doi.org/10.1088/17426596/1747/1/012034

Gunawan, G., Jufri, A. W., Nisrina, N., AlIdrus, A., \& Suranti, N. M. Y. (2020). Scientific literacy improvement with blended learning tools in rotational flipped classroom for junior high school. Solid State Technology, 63(4), 77427748.

Hadisaputra, S., Ihsan, M. S., Gunawan, G., \& Ramdani, A. (2020). The development of chemistry learning devices based blended learning model to promote students' critical thinking skills. Journal of Physics: Conference Series, 1521, 042083. https://doi.org/10.1088/1742$6596 / 1521 / 4 / 042083$

Henriksen, D., Richardson, C., \& Mehta, R. (2017). Design thinking: A creative approach to educational problems of practice. Thinking Skills and Creativity, 26, 140-153. https://doi.org/10.1016/j.tsc.2017.10.001

Hensley, N. (2020). Educating for sustainable development: Cultivating creativity through mindfulness. Journal of Cleaner Production, 243, 118542. https://doi.org/10.1016/j.jclepro.2019.118 542

Hernawati, D., Amin, M., Irawati, M., Indriwati, S., \& Aziz, M. (2018). Integration of project activity to enhance the scientific process skill and self-efficacy in zoology of vertebrate teaching and learning. EURASIA Journal of Mathematics, Science and Technology Education, 14(6), 2475-2485.

https://doi.org/10.29333/ejmste/89940

Huang, S.-Y., Kuo, Y.-H., \& Chen, H.-C. (2020). Applying digital escape rooms infused with science teaching in elementary school: Learning performance, learning motivation, and problem-solving ability. Thinking Skills and Creativity, 37, 100681. https://doi.org/10.1016/j.tsc.2020.100681

Hudha, M. N., Aji, S. D., \& Huda, C. (2018). Erubric: Scientific work based on android 
for experimental physic. IOP Conference

Series: Materials Science and

Engineering, 288(1), 012100.

https://doi.org/10.1088/1757-

899X/288/1/012100

Hudha, M. N., Hakim, A. R., Aji, S. D., Tasi, M. I., Sundaygara, C., Laksana, E. P., Fajaruddin, S., Andi, T., Yusro, A. C., \& Chaeruman, U. A. (2018). Scientific performance e-rubric-assisted problembased learning for improving learning effectiveness. In International Journal of Engineering \& Technology (Vol. 7). www.sciencepubco.com/index.php/IJET

Hugerat, M., \& Kortam, N. (2014). Improving higher order thinking skills among freshmen by teaching science through inquiry. Eurasia Journal of Mathematics, Science \& Technology Education, 10(5), 447-454.

https://doi.org/10.12973/eurasia.2014.110 $7 \mathrm{a}$

Hwang, G.-J., Lai, C.-L., Liang, J.-C., Chu, H.C., \& Tsai, C.-C. (2018). A long-term experiment to investigate the relationships between high school students' perceptions of mobile learning and peer interaction and higher-order thinking tendencies. Educational Technology Research and Development, 66(1), 75-93. https://doi.org/10.1007/s11423-017-95403

Kivunja, C. (2015). Teaching students to learn and to work well with 21 st century skills: Unpacking the career and life skills domain of the new learning paradigm. International Journal of Sustainability in Higher Education, 4(1), 1-11. https://doi.org/10.5430/ijhe.v4n1p1

Llewellyn, D. (2011). Differentiated science inquiry. Corwin Press.

Llewellyn, D. (2013). Teaching high school science through inquiry and argumentation (2nd ed.). Corwin Press.

Lott, K. H. (2011). FIRE UP the Inquiry. Lose the routine, tweak your "cookbook lab," and reach a level of open inquiry with these strategies used during a unit on heat. Science and Children, 48(7), 29-33.

Malik, A., \& Setiawan, A. (2015). The development of higher order thinking laboratory to improve transferable skills of students. Proceedings of the 2015 International Conference on Innovation in Engineering and Vocational Education, 36-40. https://doi.org/10.2991/icieve15.2016 .9

Montag-Smit, T., \& Maertz, C. P. (2017). Searching outside the box in creative problem solving: The role of creative thinking skills and domain knowledge. Journal of Business Research, 81, 1-10. https://doi.org/10.1016/j.jbusres.2017.07. 021

Munro, J. (2015). Insights into the creativity process: Identifying and measuring creativity.

Ndiung, S. (2020). The treffinger learning model with RME principles on mathematics learning outcome by considering numerical ability. Proceedings of the International Conference on Progressive Education (ICOPE 2019). https://doi.org/10.2991/assehr.k.200323.0 80

Nisrina, N., Gunawan, G., \& Harjono, A. (2017). Pembelajaran kooperatif dengan media virtual untuk peningkatan penguasaan konsep fluida statis siswa. Jurnal Pendidikan Fisika Dan Teknologi, 2(2), 66-72.

https://doi.org/10.29303/jpft.v2i2.291

Nur, S., Zubaidah, S., Mahanal, S., \& Rohman, F. (2020). ERCoRe learning model to improve creative-thinking skills of preservice biology teachers. Journal for the Education of Gifted Young Scientists, 8(1), 549-569. https://doi.org/10.17478/jegys.673022

Palaniappan, A. K. (2007). Academic achievement of groups formed based on creativity and intelligence. In L. Taxén (Ed.), The 13th International Conference on Thinking (pp. 154-151). Linköping University Electronic Press.

Pretorius, L., Mourik, G. P. van, \& Barratt, C. (2017). Student choice and higher-order thinking: Using a novel flexible assessment regime combined with critical thinking activities to encourage the development of higher order thinking. International Journal of Teaching and Learning in Higher Education, 29(2), 
389-401.

Ramadhani, R., Umam, R., Abdurrahman, A., \& Syazali, M. (2019). The effect of flippedproblem based learning model integrated with LMS-google classroom for senior high school students. Journal for the Education of Gifted Young Scientists, 7(2), 137-158.

https://doi.org/10.17478/jegys.548350

Ramdani, A., \& Artayasa, I. P. (2020). Keterampilan berpikir kreatif mahasiswa dalam pembelajaran IPA menggunakan model inkuiri terbuka. Jurnal Pendidikan Sains Indonesia (Indonesian Journal of Science Education), 8(1), 1-9. https://doi.org/10.24815/jpsi.v8i1.15394

Ratnasari, D., Suciati, S., \& Maridi, M. (2019). Empowering scientific thinking skills through creative problem solving with scaffolding learning. Jurnal Pendidikan Biologi Indonesia, 5(1), 61-68. https://doi.org/10.22219/jpbi.v5i1.7135

Romli, S., Abdurrahman, A., \& Riyadi, B. (2018). Designing students' worksheet based on open-ended approach to foster students' creative thinking skills. Journal of Physics: Conference Series, 948, 012050. https://doi.org/10.1088/17426596/948/1/012050

Rudibyani, R. B. (2019). Improving students' creative thinking ability through problem based learning models on stoichiometric materials. Journal of Physics: Conference Series, 1155, 012049. https://doi.org/10.1088/17426596/1155/1/012049

Sadeh, I., \& Zion, M. (2012). Which type of inquiry project do high school biology students prefer: Open or guided? Research in Science Education, 42(5), 831-848. https://doi.org/10.1007/s11165011-9222-9

Sarwono, J. (2015). Rumus-rumus populer dalam SPSS 22 untuk riset skripsi (A. Sahala (ed.); 1st ed.). Andi.

Siburian, J., Corebima, A. D., Ibrohim, I., \& Saptasari, M. (2019). The correlation between critical and creative thinking skills on cognitive learning results. Eurasian Journal of Educational Research, 19(81), 99-114. https://doi.org/10.14689/ejer.2019.81.6

Spires, H. A., Kerkhoff, S. N., \& Graham, A. C. K. (2016). Disciplinary literacy and inquiry: Teaching for deeper content learning. Journal of Adolescent \& Adult Literacy, 60(2), 151-161. https://doi.org/10.1002/jaal.577

Sumarni, W., \& Kadarwati, S. (2020). EthnoSTEM project-based learning: Its impact to critical and creative thinking skills. Jurnal Pendidikan IPA IndonesiaA, 9(1), $11-21$. https://doi.org/10.15294/jpii.v9i1.21754

Suryawati, E., \& Osman, K. (2018). Contextual learning: Innovative approach towards the development of students' scientific attitude and natural science performance. Eurasia Journal of Mathematics, Science and Technology Education, 14(1), 61-76. https://doi.org/10.12973/ejmste/79329

Syuhendri, S. (2017). A learning process based on conceptual change approach to foster conceptual change in Newtonian mechanics. Journal of Baltic Science Education, 16(2), 228-240. https://doi.org/10.33225/jbse/17.16.228

Trnova, E., \& Trna, J. (2014). Implementation of creativity in science teacher training. International Journal on New Trends in Education and Their Implications, 5(3), 54-63.

Wahyudi, W., Verawati, N. N. S. P., Ayub, S., \& Prayogi, S. (2019). The effect of scientific creativity in inquiry learning to promote critical thinking ability of prospective teachers. International Journal of Emerging Technologies in Learning (IJET), 14(14), 122. https://doi.org/10.3991/ijet.v14i14.9532

Yulianti, D., Wiyanto, W., Rusilowati, A., \& Nugroho, S. E. (2020). Student worksheets based on Science, Technology, Engineering and Mathematics (STEM) to facilitate the development of critical and creative thinking skills. Journal of Physics: Conference Series, 1567, 022068. https://doi.org/10.1088/17426596/1567/2/022068

Yusnaeni, Y., Corebima Aloysius, D., Susilo, H., \& Zubaidah, S. (2017). Creative 
thinking of low academic student undergoing search solve create and share learning integrated with metacognitive strategy. International Journal of Instruction, 10(2), 245-262. https://doi.org/10.12973/iji.2017.10216a

Yustiqvar, M., Gunawan, G., \& Hadisaputra, S. (2019). Effects of green chemistry based interactive multimedia on the students' learning outcomes and scientific literacy. Journal of Advanced Research in Dynamical and Control Systems, 11(7),
664-674.

Zion, M., \& Mendelovici, R. (2012). Moving from structured to open inquiry: Challenges and limits. Science Education International, 23(4), 383-399.

Zubaidah, S., Fuad, N. M., Mahanal, S., \& Suarsini, E. (2017). Improving creative thinking skills of students through differentiated science inquiry integrated with mind map. Journal of Turkish Science Education, 14(4), 77-91. 